\title{
GAKUSHUIN \\ NATURAL RADIOCARBON MEASUREMENTS III
}

\author{
KUNIHIKO KIGOSHI, DER-HWANG LIN, ${ }^{*}$ and KUNIHIKO ENDO
}

Department of Physics and Chemistry, Gakushuin University

Mejiro Toshimaku, Tokyo, Japan

This date list covers many of the datings done from November 1962 to October 1963. The instruments and technique used for this work are essentially the same as those used for the previous work (Gakushuin II). Age calculations are based on the Libby half life of $\mathrm{C}^{14}, 5570 \pm 30 \mathrm{yr}$. The errors quoted are the standard deviations obtained from the number of counts only. When observed activities are less than $2 \sigma$ above background, infinite dates are given with a limit corresponding to the activity of $3 \sigma$, and when they are greater than the activity of $95 \%$ of NBS oxalic-acid standard minus $2 \sigma$, modern dates are given with the limit equal to $3 \sigma$ below the $95 \%$ of NBS standard.

\section{ACKNOWLEDGMENTS}

The authors are indebted to M. Oda, S. Saito and other members of the Institute of Nuclear Study, University of Tokyo, for supplying wood specimens taken from Yaku Island. Technical assistance has been provided by Hiromi Kobayashi and Tamako Morinaga. Grateful acknowledgment is made to many donors and collectors of samples for descriptions and comments.

\section{SAMPLE DESCRIPTIONS}

I. TREE RING SAMPLES

\section{Yaku-sugi series, Kyushu}

Wood of Cryptomeria japonica from Yaku Island, Kyushu $\left(0^{\circ} 40^{\prime} \mathrm{N}\right.$ Lat, $130^{\circ} 30^{\prime}$ E Long). Coll. 1960 and subm. by Minoru Oda, Univ. of Tokyo. The tabulated $\delta \mathrm{C}^{14}$ are computed as age-corrected $\mathrm{C}^{14}$ concentrations, taking 95\% of NBS standard as modern activity, not corrected for isotopic fractionation. Errors quoted do not include the errors on the activity measurements of NBS standard. Comment: tree has 1821 growth rings, and was probably cut in A.D. 1950. Wood samples dated by tree ring counting may have errors less than $50 \mathrm{yr}$. Thin sliced wood samples were treated for ca. $30 \mathrm{~min}$ with hot $5 \%$ NaCIO solution.

GaK-270:1. Yaku-sugi-29 $\delta \mathrm{C}^{14}, \%$

From A.D. 710 to A.D. 729 .

GaK-270:2. Yaku-sugi-34

$\mathbf{2} \pm \mathbf{5 . 9}$

From A.D. 810 to A.D. 829.

GaK-270:3. Yaku-sugi-46 $-7 \pm 2.2$

From A.D. 1050 to A.D. 1069.

* Permanent address: Department of Chemistry, National Taiwan University. 
GaK-270:4. Yaku-sugi-50 $-7 \pm 3.5$

From A.D. 1130 to A.D. 1149.

GaK-270:5. Yaku-sugi-54

From A.D. 1210 to A.D. 1229.

GaK-270:6. Yaku-sugi-60

$-5 \pm 2.0$

From A.D. 1330 to A.D. 1349.

GaK-270:7. Yaku-sugi-66

From A.D. 1450 to A.D. 1469.

$-12 \pm 1.9$

$-3 \pm \mathbf{2} .2$

II. GEOLOGIC SAMPLES

\section{Ariake series, Kyushu}

\section{A. Japan}

Samples from Ariake area, Nagasaki and Saga Prefectures, Kyushu. Connected with the eruptions of Unzen and Aso Volcano. Coll. 1962 by Ariake Research Group.

\section{GaK-272. Kuriyagawa}

$$
\begin{array}{cr}
\mathbf{3 3 , 2 0 0} & +\mathbf{3 8 0 0} \\
\mathbf{3 1 , 2 5 0} \text { в.с. } &
\end{array}
$$

Wood from bank of the Kuriya, Taira, Takaki-gun, Nagasaki Prefecture $\left(32^{\circ} 52^{\prime} \mathrm{N}\right.$ Lat, $130^{\circ} 20^{\prime} \mathrm{E}$ Long), imbedded in tuffaceous clay of Older Unzen pyroclastics. Coll. and subm. by Tsuhei Hoshino, Maritime Safety Agency.

\section{GaK-283. Oumisaki}

$$
\begin{aligned}
& 30,600 \pm 3000 \\
& 28,650 \text { в.c. }
\end{aligned}
$$

Charcoal from Matsuobashi, Ariakemura, Nagasaki Prefecture $\left(32^{\circ} 49^{\prime}\right.$ $50^{\prime \prime} \mathrm{N}$ Lat, $130^{\circ} 21^{\prime} \mathrm{E}$ Long), imbedded in volcanic mudflow from Maidake, Unzen Volcano, ca. $5 \mathrm{~m}$ below surface. Coll. and subm. by Tomoyuki Shinbori, S. K. Kenkyu-sho. Comment (T.S.) : dates an eruption of Unzen Volcano. Stratigraphically, a younger date than that for the Aso Lava (GaK-274) was expected.

\section{GaK-274. Shimabara 1}

$$
22,100 \pm 900
$$$$
\text { 20,150 в.C. }
$$

Wood from Harajooshi Minami-arimamachi Nagasaki Prefecture $\left(32^{\circ}\right.$ 37.5' N Lat, $130^{\circ} 15.5^{\prime} \mathrm{E}$ Long), ca. $5 \mathrm{~m}$ above sealevel, imbedded in Ōe Layer underlain by Aso Lava. Coll. and subm. by Yukio Kuwano, S. K. Kenkyu-sho. Comment: Ōe layer is twofold, consisting of a lower layer of sandy silt containing fossil plants, and an upper one of shell beds. On age of the latter see GaK-319 of this series.

GaK-319. Shimabara 2

$$
\begin{aligned}
& 19,400 \pm 700 \\
& 17,450 \text { в.c. }
\end{aligned}
$$

Shell of Rapana thomasiana from same site as GaK-274, ca. 7 m above sealevel, imbedded in Ōe Marine layer. Coll. and subm. by Y. Kuwano.

GaK-282. Yame

$$
\begin{array}{cc}
32,600 & +3200 \\
30,650 & -2300 \\
\text { в.C. }
\end{array}
$$

Charcoal from Oota, Hirokawacho, Yamegun, Fukuoka Prefecture $\left(33^{\circ}\right.$ 
$13.7^{\prime} \mathrm{N}$ Lat, $130^{\circ} 32.5^{\prime} \mathrm{E}$ Long), $3.2 \mathrm{~m}$ below surface, imbedded in lower layer of Yame pumice flow. Coll. by Y. Gohara and T. Shinbori; subm. by Y. Gohara, S. K. Kenkyu-sho. Comment (Y.G.) : lower layer of Yame pumice flow is correlative with the Aso Lava. More accurate dates are needed to show the relationship between them.

GaK-273. Shimabara 3

Charcoal from near the site of GaK-274 $\left(32^{\circ} 37.5^{\prime} \mathrm{N}\right.$ Lat, $130^{\circ} 16^{\prime} \mathrm{E}$ Long), imbedded in base of Aso Lava (welded tuff), $1.9 \mathrm{~m}$ thick. Coll. and subm. by Y. Gohara. Comment (Y.G.) : dates Aso Lava and an eruption of Aso Volcano.

\section{GaK-284. Imari}

$26,350 \pm 1100$

24,400 в.C.

Clay containing small fragments of wood from Imari City, Saga Prefecture ( $33^{\circ} 16^{\prime} \mathrm{N}$ Lat, $129^{\circ} 52^{\prime}$ E Long). Coll. and subm. by Kōzi Suzuki, S. K. Kenkyu-sho. Comment (K.S.) : field relations suggest that sample came from one of the Yame pumice flows dated by GaK-282. Date does not positively support the view.

\section{GaK-329. Tokushima}

$14,500 \pm 600$

Peat from boring at Kotashima, Anan City, Tokushima $\left(33^{\circ} 53^{\prime} 15^{\prime \prime} \mathrm{N}\right.$ Lat, $134^{\circ} 39^{\prime} 46^{\prime \prime} \mathrm{E}$ Long), $23 \mathrm{~m}$ from surface, in silty clay overlain by fine sand and underlain by sandy gravel. Coll. 1962 by Fukada Geol. Inst.; subm. by Kazumi Suyari, Univ. of Tokushima. Comment (K.S.) : dates base of alluvial deposit.

\section{Osaka marine layer series}

Shells from marine sand in Osaka area. Coll. and subm. by Hikotaro Kajiyama, Juso P. O. Comment: series dates a marine layer of ca. 5000 в.P., as does GaK-166, $4840 \pm 120$ (Gakushuin I).

\section{GaK-278. Kadoma}

$6110 \pm 160$

\section{B.c.}

Dosinia angulosa, Macoma tokyoensis and Anodontia sternsiana from Mitsushima Kadoma City, Osaka (34 $42^{\prime} 41^{\prime \prime}$ N Lat, $135^{\circ} 35^{\prime} 32^{\prime \prime}$ E Long), alt $2.5 \mathrm{~m}, 7 \mathrm{~m}$ below surface. Coll. 1962 .

\section{GaK-279. Ogimachi}

$4870 \pm 150$

2920 B.c.

Callista chinensis and Dosinia japonica from site of Yomiuri Building, Ogimachi, Osaka ( $34^{\circ} 41^{\prime} 53^{\prime \prime} \mathrm{N}$ Lat, $135^{\circ} 30^{\prime} 23^{\prime \prime}$ E Long), alt $3.5 \mathrm{~m}, 10 \mathrm{~m}$ below surface. Coll. 1954.

\section{GaK-293. Toyonaka}

$4450 \pm 140$

2500 в.c.

Mya japonica, Meretrix lusoria, Anadara subcrenata and Dosinia japonica from Hattori, Toyonaka City (34 ${ }^{\circ} 45^{\prime} 28^{\prime \prime} \mathrm{N}$ Lat, $135^{\circ} 28^{\prime} 22^{\prime \prime}$ E Long), alt $4.0 \mathrm{~m}, 3$ to $4 \mathrm{~m}$ below surface. Late Yayoi pottery was found 1 to $2 \mathrm{~m}$ below surface. Coll. 1953. 


\section{Sakai City series, Osaka}

Wood and peaty clay from Sakai City, taken from the deposits overlain by alluvium and underlain by the Pleistocene Osaka Group, both unconformably. Dates were expected to provide correlation between buried deposits and nearby terrace cut in alluvium. Subm. by Nobuo Ikebe and Junnosuke Takenaka, Osaka City Univ. Comment (N.I.) : greater age of the clayey sediments (GaK$320)$ than of the terrace deposits (GaK-321) agrees with geological evidence.

\section{GaK-320. Ohama Park}

$>32,000$

Wood from boring $1.5 \mathrm{~km}$ off the coast of Ohama Park, Sakai City $\left(34^{\circ}\right.$ $34^{\prime} 30^{\prime \prime} \mathrm{N}$ Lat, $135^{\circ} 26^{\prime} \mathrm{E}$ Long), imbedded in sandy gravel, $23 \mathrm{~m}$ below sealevel. Base of alluvial deposit at this site is 5 to $10 \mathrm{~m}$ below sealevel. Coll. 1962 by N. Ikebe.

\section{GaK-321. Ebaradera}

$23,700 \pm 1100$ 21,750 в.C.

Wood from Ebaradera, Sakai City ( $34^{\circ} 30^{\prime} \mathrm{N}$ Lat, $135^{\circ} 28^{\prime} 30^{\prime \prime}$ E Long), imbedded in alluvium underlying terrace, $25 \mathrm{~m}$ above sealevel. Coll. 1963 by J. Takenaka.

\section{GaK-322. Toyota}

$16,800 \pm 500$ 14,850 в.с.

Wood fragments from Toyota, Sakai City $\left(34^{\circ} 29^{\prime} 11^{\prime \prime} \mathrm{N}\right.$ Lat, $135^{\circ} 30^{\prime}$ $30^{\prime \prime} \mathrm{E}$ Long), imbedded in clayey sand underlain unconformably by the terrace alluvium at alt $55 \mathrm{~m}$. Coll. 1963 by J. Takenaka.

\section{GaK-175. Lake Biwa, Shiga Prefecture $\quad 28,500 \pm 2500$ 26,550 в.c.}

Wood from the lacustrine terrace (T-3) of Takashima-gun, Shiga Prefecture ( $35^{\circ} 19^{\prime} \mathrm{N}$ Lat, $135^{\circ} 58^{\prime} \mathrm{E}$ Long), alt $135 \mathrm{~m}$, in W part of Lake Biwa basin. Sample was imbedded in sand layer overlain by subrounded gravels. Coll. 1959 and subm. by S. Horie, Kyoto Univ.

\section{GaK-312. Yokoyama, Nagano}

$28,400 \pm 1800$

26,450

Charred wood from Yokoyama, Kawanishimura, Nagano $\left(36^{\circ} 22^{\prime} \mathrm{N}\right.$ Lat, $138^{\circ} 10^{\prime} \mathrm{E}$ Long), imbedded in peat in Shiota Layer. Coll. and subm. by Namio Iijima, Shinshu Univ. Comment: in addition to the peat, Shiota layer contains several fossils of Elephas namadicus naumanni, horse and Megaceros. See GaK-161, 15,750 \pm 390 (Gakushuin I) for date of related Totchu deposit; and Lake Nojiri series, this date list.

\section{Lake Nojiri series, Nagano}

Wood samples from W side of Lake Nojiri, Tachigahana, Nagano $\left(36^{\circ} 50^{\prime}\right.$ $\mathrm{N}$ Lat, $138^{\circ} 14^{\prime} 56^{\prime \prime} \mathrm{E}$ Long), imbedded in lacustrine sediments. Samples associated with Megaceros and Elephas namadicus naumanni, and upper layer contained a Paleolithic culture. Coll. 1962; subm. by Lake Nojiri Research Group, Univ. of Nagano.

\section{GaK-267. Nojiri 1}

$16,150 \pm 550$

$40 \mathrm{~cm}$ below surface. 
GaK-268. Nojiri 2

$61 \mathrm{~cm}$ below surface.

GaK-269. Nojiri 3

$97 \mathrm{~cm}$ below surface.

\section{Takata series}

Drift wood from Koizumi, Naoetsu City ( $37^{\circ} 8^{\prime}$ N Lat, $138^{\circ} 15^{\prime}$ E Long), alt $8.3 \mathrm{~m}$, imbedded in alluvial deposit of Takata plain. Coll. 1962; subm. by Takata Plain Research Group, Takata High School. Comment: dates end of marine and beginning of terrestrial deposition.

GaK-280. Koizumi $-250 \mathrm{~cm}$

GaK-281. Koizumi $-256 \mathrm{~cm}$

\section{GaK-311. Komoro, Nagano}

Charred wood from S side of Komoro Electric Power Dam, Komoro City $\left(36^{\circ} 19^{\prime} \mathrm{N}\right.$ Lat, $138^{\circ} 25.4^{\prime} \mathrm{E}$ Long), imbedded in pumice flow II of Asama Volcano. Coll. 1962; subm. by Kunio Kobayashi, Shinshu Univ. Comment (K.K.) : correlative to Itahana yellow pumice, dated as $13,130 \pm 230$ by GaK-159 (Gakushuin I).

\section{GaK-318. Rengeji, Gotemba 2}

$16,500 \pm 400$

14,550 в.C.

Partly charred wood from Rengeji, Gotemba City $\left(35^{\circ} 19^{\prime} 16^{\prime \prime}\right.$ N Lat, $138^{\circ} 58^{\prime}$ E Long), imbedded in peaty clay overlain by Upper Tachikawa Loam. Coll. 1961 by Koji Suzuki, S. K. Kenkyu-sho; subm. by Yukiko Mori, Meijo Gakuen, Tokyo. Comment (Y.M.) : dates an eruption of Old Fuji Volcano, older than that dated as $3800 \pm 130$ (GaK-203, Gakushuin II) .

\section{GaK-275. Toyano, Fukushima}

$21,000 \pm 850$ 19,050 в.с.

Wood from bank of the Abukuma, Toyano, Fukushima $\left(37^{\circ} 43^{\prime} 40^{\prime \prime} \mathrm{N}\right.$ Lat, $140^{\circ} 28^{\prime} 32^{\prime \prime}$ E Long), imbedded in peaty layer in clay overlain unconformably by alluvial gravels. Associated with pollen of Juglans, Styrax, Alnus, Picea and Pinus koraiensis. Coll. 1962; subm. by Noriko Tomiyama, Fukushima Univ. Comment: dates formation of Fuskushima basin, in approximate agreement with GaK-209, 25,400 \pm 1150 (Gakushuin II). The overlying gravel layer was dated $6370 \pm 110$ by GaK-208.

\section{GaK-176. Ichinome-gata, Akita}

$$
9070 \pm 400
$$$$
7120 \text { в.c. }
$$

Wood from lacustrine terrace of a closed lake named Ichinome-gata, Akita $\left(39^{\circ} 57^{\prime} \mathrm{N} \mathrm{Lat}, 139^{\circ} 44^{\prime} \mathrm{E}\right.$ Long), alt $88 \mathrm{~m}$, imbedded in silt several meters above lake level. Coll. 1955; subm. by S. Horie. Comment (S.H.) : dates lacustrine terrace formed during a rainier time of higher lake level. 
GaK-177. Lake Inawashiro, Fukushima

Wood from sand and sandy clay layer of lacustrine terrace of Lake Inawashiro, Fukushima $\left(37^{\circ} 28^{\prime} \mathrm{N}\right.$ Lat, $140^{\circ} 6^{\prime} \mathrm{E}$ Long $)$, alt $514 \mathrm{~m}$, ca. $30 \mathrm{~cm}$ above bank of river that has trenched the lacustrine terrace, and $4 \mathrm{~m}$ below terrace surface. Coll. 1961; subm. by S. Horie. Comment (S.H.) : date indicates that former high lake level was sometime during the late Pleistocene.

\section{GaK-178. Lake Tazawa, Akita $\quad 2490 \pm 100$ $\mathbf{5 4 0}$ в.c.}

Wood from silt layer of lacustrine terrace of extinct closed Lake Tazawa, situated in a caldera, Akita $\left(39^{\circ} 43^{\prime} \mathrm{N}\right.$ Lat, $140^{\circ} 40^{\prime} \mathrm{E}$ Long $)$, alt $250 \mathrm{~m}$. Coll. 1951 ; subm. by S. Horie. Comment (S.H.) : date is minimum for age of the caldera and of the high lake level.

\section{GaK-314. Hanayama, Miyagi $\quad 27,900 \pm 1700$ 25,950 в.c.}

Drift wood, perhaps Cryptomeria japonica, from Zasu, Hanayama-mura, Miyagi Prefecture $\left(38^{\circ} 47^{\prime} 30^{\prime \prime} \mathrm{N}\right.$ Lat, $140^{\circ} 50^{\prime} 47^{\prime \prime} \mathrm{E}$ Long), imbedded in lacustrine sediments, $1.5 \mathrm{~m}$ below surface. Coll. 1962; subm. by Keiji Oide, Tohoku Univ. Comment (K.O.) : sediments contain pisolite and volcanic ash which are common in several lacustrine layers found along the line from Naruko via Zasu and Nakayama-daira to Mukai-machi Basin, Yamagata Prefecture. Sediments in one of these lacustrine layers at Onikobe were described by Shimada (1955).

\section{GaK-344. Rishiri Island}

$$
\begin{aligned}
& 20,800 \pm 1000 \\
& 18,850 \text { в.c. }
\end{aligned}
$$

Charcoal from $\mathrm{N}$ coast of Rishiri I., Fujino Sagidomari, Rishiri-gun, Hokkaido (45 $15.2^{\prime} \mathrm{N}$ Lat, $141^{\circ} 12.5^{\prime} \mathrm{E}$ Long), alt $10 \mathrm{~m}$, from just below basalt lava flow that is underlain by a Miocene marine layer. Coll. 1962 by Kazunori Matsui; subm. by Konosuke Sawamura, Geol. Survey of Japan. Comment: dates the basalt lava flow. On the petrology of the lava, see Y. Katsui (1953).

\section{East Ongul Island series}

\section{B. Antarctica}

Molluscan shells and foraminifera from East Ongul I. $\left(69^{\circ} 1^{\prime} \mathrm{S}\right.$ Lat, $39^{\circ}$ 34' E Long). Coll. and subm. 1962 by Japanese Antarctic Research Exped. Comment: topographic evidence indicates that part of Ongul I. was submerged beneath the sea and then uplifted ca. $20 \mathrm{~m}$ after the shrinkage of the ice sheet. Dates show the retreat of ice from Ongul I. took place at least 23,000 B.P., although dates are not well ordered in relation to alt. The reduction of age by admixture of recent shells is possible. Other measurements in this series are GaK-200 and 201 (Gakushuin I). Sampling, topography and species of associated foraminifera are described by Megro et al. (1963).

GaK-285. Kitamihama 1

$25,400 \pm 1200$ 23,450 в.c.

Molluscan shell fragments from Kitamihama, N-facing beach of East Ongul I., alt 7 to $8 \mathrm{~m}$. 
GaK-289. Kitamihama 2

$31,200 \quad+2500$

29,250 в.c.

Foraminifera mixed with a few echinoid spines from the site of GaK-285. Alt 7 to $8 \mathrm{~m}$.

GaK-286. Kitamihama 3

$34,000+3000$

32,050 в.C.

Molluscan shell fragments from Kitamihama, alt $12 \mathrm{~m}$.

GaK-287. Kainohama 1

$22,800 \pm 1000$

20,850 в.c.

Molluscan shell fragments from Kainohama, alt 9 to $10 \mathrm{~m}$.

GaK-288. Kainohama 2

$29,500 \quad \begin{array}{r}+2400 \\ -1800\end{array}$

27,550 в.c.

Molluscan shell fragments from Kainohama, alt 3 to $4 \mathrm{~m}$.

\section{Madagascar}

GaK-277. Baie des Galions

Shell from a wave-cut notch at Baie des Galions, $\mathrm{S}$ of Madagascar $\left(25^{\circ}\right.$ $30^{\prime} \mathrm{S}$ Lat, $46^{\circ} 30^{\prime} \mathrm{E}$ Long). Notch is 1 to $1.4 \mathrm{~m}$ above the similar notch corresponding to present sealevel. Coll. 1957 and subm. by R. Battistini, Univ. de Madagascar. Comment (R.B.) : dates the period in which sealevel was 1 to 1.4 $\mathrm{m}$ higher than present level. Similar notches are frequent on $\mathrm{S}$ and $\mathrm{W}$ coasts of Madagascar (Battistini, 1958).

\section{ARCHAEOLOGIC SAMPLES}

\section{Platte County series}

\section{A. North America}

Charcoal samples from burial mound and remains of house of the SteedKisker focus of the Middle Mississippi Culture, Platte County, Missouri. Coll. and subm. by M. Shippee, Univ. of Missouri.

\section{GaK-266. Platte County 1}

$$
660 \pm 80
$$

Charcoal from burial mound (C), $\left(39^{\circ} 42^{\prime} \mathrm{N}\right.$ Lat, $94^{\circ} 40^{\prime} \mathrm{W}$ Long $), 30$ to 36 in. from the surface. Coll. 1958.

\section{GaK-330. Platte County 2}

$$
\text { A.D. } 1260
$$

$$
690 \pm 90
$$

Charcoal from a large post lying on floor of a house $\left(39^{\circ} 15^{\prime} \mathrm{N}\right.$ Lat, $94^{\circ}$ 40’ W Long). Coll. 1962.

\section{GaK-295. Clay County}

$$
750 \pm 120
$$

\section{A.D. 1200}

Charcoal from a small storage pit in floor of House 2 at site 14CY30, Clay County, Kansas $\left(30^{\circ} 14^{\prime} 10^{\prime \prime} \mathrm{N}\right.$ Lat, $96^{\circ} 58^{\prime} 45^{\prime \prime} \mathrm{W}$ Long). Site is an earthlodge site belonging to the Smoky Hill Aspect of the Central Plains Phase. Coll. 1961 and subm. by T. A. Witty, Kansas State Hist. Soc. Comment 
(T.A.W.) : date agrees very closely with date from House 1, A.D. $1176 \pm 150$ (M-113, Michigan I) .

\section{GaK-296. Two Dog site, Kansas}

Charcoal from the Two Dog site, 14M0301, Morris County, Kansas $\left(38^{\circ}\right.$ $14^{\prime} 13^{\prime \prime} \mathrm{N}$ Lat, $96^{\circ} 31^{\prime} 50^{\prime \prime} \mathrm{W}$ Long), a village site belonging to the Middle Woodland Pattern. Sample was taken from occupation level at the site, associated with conical based pot. Coll. 1962 and subm. by T. A. Witty. Comment (T.A.W.) : while date appears late for this artifacts inventory, it might show that Middle Woodland peoples were still occupying the Flint Hills area in this period. More work is needed on this problem. See T. A. Witty (1962a).

\section{GaK-297. William Young site, Kansas}

$5340 \pm 160$

3390 в.c.

Charcoal from William Young site, 14M0304, an Archaic campsite to be asigned to the Mumkers Creek Focus, Morris County, Kansas ( $38^{\circ} 44^{\prime} 50^{\prime \prime} \mathrm{N}$ Lat, $96^{\circ} 31^{\prime} 28^{\prime \prime} \mathrm{W}$ Long). Sample was taken from center of occupation zone, associated with lanceolate-shaped points, large chipped stone blades and fired clay effigy heads. Coll. 1963 by W. Frantz, Kansas State Hist. Soc.; subm. by T. A. Witty. Comment (T.A.W.) : the dating and artifacts identify a hitherto unrecognized Archaic complex (Witty, 1962a).

\section{GaK-298. Slough Creek site, Kansas \\ $390 \pm 120$}

Portion of a burned lodge post taken from House 1 in Slough Creek site, 14M0308, Morris County, Kansas ( $38^{\circ} 42^{\prime}$ N Lat, $96^{\circ} 32^{\prime} 20^{\prime \prime}$ W Long). Associated stone artifacts are Middle Woodland specimens but pottery and house features share traits with the later Central Plains Phase. Coll. 1962 by W. Frantz; subm. by T. A. Witty. Comment (T.A.W.) : date is too late for the traits (Witty, 1962a). Another sample should be processed.

\section{GaK-306. Morris mound, Kansas \\ $2570 \pm 110$ \\ 620 B.C.}

Charcoal from center of Morris mound 14M0314, Morris County, Kansas $\left(38^{\circ} 42^{\prime} 50^{\prime \prime} \mathrm{N} \mathrm{Lat}, 96^{\circ} 32^{\prime} 7^{\prime \prime} \mathrm{W}\right.$ Long). Sample was part of central burial complex, associated with Snyder-like blades. Coll. 1962 and subm. by T. A. Witty. Comment: see T. A. Witty (1962 a,b).

\section{Naniwa-gu series, Osaka}

\section{B. Japan}

Wood from remains of royal palace Naniwa-gu, probably constructed in the Shomu period (ca. A.D. 700), Hoensakamachi Higashiku, Osaka $\left(34^{\circ} 40^{\prime}\right.$ $\mathrm{N}$ Lat, $135^{\circ} 31^{\prime} \mathrm{E}$ Long). Coll. and subm. by Tokutaro Yamane, Osaka City Univ. Comment: see report by T. Yamane et al. (1956) and GaK-114 (Gakushuin I) .

\section{GaK-294. Naniwa-gu 1}

$$
910 \pm 90
$$

Base of wooden pole still erect in ground. Comment (T.Y.) : date seems too young. 
GaK-324. Naniwa-gu 2

Wooden plate of Cryptomeria japonica taken from $3.6 \mathrm{~m}$ from surface. Sample has more than 100 tree rings. Coll. 1954. Comment (T.Y.) : probably implies a maximum age of the construction of Naniwa Takatsu-gu.

\section{GaK-292. Morinomiya, Osaka}

$$
1800 \pm 120
$$

\section{A.D. 150}

Shells of Corbicula sandai from remains of shelter at Morinomiya, Higashi-ku, Osaka ( $34^{\circ} 40^{\prime} 39^{\prime \prime} \mathrm{N}$ Lat, $135^{\circ} 31^{\prime} 55^{\prime \prime} \mathrm{E} \mathrm{Long}$ ), alt $7.0 \mathrm{~m}$. Coll. 1960 and subm. by H. Kajiyama.

\section{GaK-301. Kaide, Kyoto}

$$
1970 \pm 120
$$

Charred wood from midden exposed by construction of Tokaido Railway, Minami-hichihanda Kaide, Otokuni-gun, Kyoto $\left(35^{\circ} 0^{\prime} \mathrm{N}\right.$ Lat, $135^{\circ} 45^{\prime} \mathrm{E}$ Long), $1 \mathrm{~m}$ below surface. Associated with Middle Yayoi pottery. Coll. 1962 and subm. by Shuichi Nakayama, Education Comm. Kyoto.

\section{Fukumachi series, Fukui}

Wood samples from remains of artificial waterway for rice-field, Fukumachi, Fukui City ( $36^{\circ} 3^{\prime} \mathrm{N}$ Lat, $136^{\circ} 11^{\prime} \mathrm{E}$ Long), alt $4 \mathrm{~m}$. Sediments in this waterway contain Late Yayoi pottery. Coll. 1962 by Seiji Onishi, Fukui Univ.; subm. by S. Miura. Comment (S.O.) : dates the construction of waterway and Late Yayoi Period on the Japan Sea coast.

\section{GaK-315. Fukumachi 1}

$$
1850 \pm 90
$$

Pile driven into sandy sediments of waterway. Top of the pile was at the boundary of sand and clay, $2 \mathrm{~m}$ below present surface.

\section{GaK-316. Fukumachi 2}

$$
1570 \pm 100
$$

Pile driven into sandy sediments. Top is $30 \mathrm{~cm}$ above boundary of sand and clay, $1.7 \mathrm{~m}$ below present surface.

\section{GaK-317. Fukumachi 3}

$$
\begin{array}{r}
1460 \pm 100 \\
\text { A.D. } 490
\end{array}
$$

Drift wood taken from sandy sediments in the waterway, $2 \mathrm{~m}$ below present surface.

\section{GaK-309. Togimachi, Ishikawa}

$$
\begin{array}{r}
900 \\
\text { A.D. } 1050
\end{array}
$$

Charcoal from peaty humic layer in sand dune, Sakami Togimachi, Ishikawa Prefecture $\left(27^{\circ} 8^{\prime} \mathrm{N}\right.$ Lat, $136^{\circ} 42^{\prime} \mathrm{E}$ Long) associated with Middle Jomon pottery and stone ware. Coll. 1962 and subm. by Norio Fuji, Kanazawa Univ. Comment: date seems too young, but association of charcoal and pottery may be secondary result of dune movement.

\section{GaK-310. Sakanomiya, Kanazawa}

$1690 \pm 80$

Shells from shell mound, Sakanomiya Tsukikage, Ishikawa Prefecture $\left(36^{\circ} 38^{\prime} \mathrm{N}\right.$ Lat, $136^{\circ} 43^{\prime} \mathrm{E}$ Long), associated with Yayoi pottery. Coll. 1959 by Y. Yoshioka; subm. by N. Fuji. 


\section{Australia}

GaK-334. Noola Rockshelter

$11,600 \pm 400$

9650 в.c.

Charcoal from hearth at depth of $121 \mathrm{in.}$ in a horizon containing a flaked pebble chopper, Noola Rockshelter via Rylstone, New South Wales $\left(33^{\circ} 0^{\prime} \mathrm{S}\right.$ Lat, $149^{\circ} 57^{\prime}$ E Long). Coll. 1963; subm. by N. B. Tindale, South Australian Mus. Comment: charcoal was very finely dispersed in deposit of kaolin and quartz sand derived from weathering of shelter; it was separated by elutriation and treated with acid. Upper portion of this excavated section, to a depth of 96 in., was reported by N. B. Tindale (1961) .

\section{GaK-335. Lake Menindee $\quad \mathbf{1 8 , 8 0 0} \pm \mathbf{8 0 0}$ 16,850 в.с.}

Charcoal from hearth in Area II, top of Layer B, Lake Menindee, New South Wales $\left(32^{\circ} 18^{\prime} \mathrm{S}\right.$ Lat, $142^{\circ} 20^{\prime}$ E Long). Coll. 1962; subm. by N. B. Tindale. Comment: fine charcoal powder was separated from sand by elutriation and treated with acid. (N.T.) The hearth lies stratigraphically above a stone implement found in Layer B. The bones of extinct Australian mammals are abundant in Bed B. See Tindale (1955).

\section{GaK-336. Cape Northumberland}

$1470 \pm 120$

Charcoal from lowest occupation horizon at edge of cliff at depth of $4 \mathrm{ft}$, Cape Northumberland, South Australia ( $38^{\circ} 1^{\prime}$ S Lat, $140^{\circ} 57^{\prime}$ E Long). Charcoal was mixed with wind-blown shell sand. Coll. 1961; subm. by N. B. Tindale. Comment (N.T.) : dates the earliest local occupation by a people who used the relatively unstained blue-black flint implements of the Murundian Culture. See Tindale (1957).

\section{GaK-337. Shellharbour}

\section{A.D. 1810}

$140 \pm 100$

Charcoal from the basal 1 in. of the occupation horizon, Shellharbour, New South Wales $\left(34^{\circ} 37^{\prime} \mathrm{S}\right.$ Lat, $150^{\circ} 37^{\prime}$ E Long); mixed with wind-blown sand and shells. Coll. 1962; subm. by N. B. Tindale. Comment (N.T.) : a late occupation site with pebble end-chopping tools and food shell debris on the present sea shore. Site rests on dunes which were formed over earth and rock considered to have been planed off by seas of the 10-ft (Later Peronian) terrace period.

\section{Madagascar}

\section{GaK-276. Talaky}

\section{$\mathbf{8 4 0} \pm \mathbf{8 0}$}

Charcoal from $1 \mathrm{mi} \mathrm{E}$ of Talaky Ambany, Tsihombe, Madagascar $\left(28^{\circ}\right.$ $28^{\prime} \mathrm{S}$ Lat, $48^{\circ} 21^{\prime} \mathrm{E}$ Long), in a fireplace located in Sq. C4 and C5 of 2nd site in $\mathrm{B}$ zone, $20 \mathrm{~cm}$ below surface. Associated with pottery, iron hooks and other artifacts. Coll. and subm. 1962 by P. Vérin, Univ. de Madagascar. Comment (P.V.) : date indicates that iron was known in the beginning of the second millenium in the area, when Aepyornis maximus was abundant. For a detailed description see Battistini et al. (1963). 
Date lists:

\section{REFERENCES}

$\begin{array}{ll}\text { Gakushuin I } & \text { Kigoshi, Tomikura and Endo, } 1962 \\ \text { Gakushuin II } & \text { Kigoshi and Endo, 1963 } \\ \text { Michigan I } & \text { Crane, 1956 }\end{array}$

Battistini, R., and Vérin, P., 1963, Le site de Talaky, contexte géologique, premiers travaux de fouille, étude de village actuel: Annales de l'Univ. de Madagascar, no. 1, in press. Battistini, R., 1958, Note sur l'existence d'encoches fossiles de corrosion marine dans la Baie des Galions: Mém. Inst. sci. Madag., f. II, p. 79-87.

Crane, H. R., 1956, University of Michigan radiocarbon dates I: Science, v. 124, p. 664-672. Katsui, Y., 1953, Petro-chemical study on the lavas from Volcano Rishiri: Jour. Faculty Sci. Hokkaido Univ., v. 8, p. 112-123.

Kigoshi, K., and Endo, K., 1963, Gakushuin natural radiocarbon measurements II: Radiocarbon, v. 5, p. 109-117.

Kigoshi, K., Tomikura, Y., and Endo, K., 1962, Gakushuin natural radiocarbon measurements I: Radiocarbon, v. 4, p. 84-94.

Megro, H., Yoshida, Y., Uchio, T., Kigoshi, K., and Sugawara, K., 1963, Quaternary marine sediments and their geologic dates with reference to the geomorphology of Prince Olav Coast, Antarctica: Paper presented at the Symposium on Antarctic Geology, Cape Town, 1963, in press.

Shimada, I., 1955, Sedimentological studies on paleo lake basins-On the sedimentation of the lake deposits in the Onikobe Basin, Miyagi Prefecture, Japan: Jour. Geol. Soc. Japan, v. 6l, p. 218-226.

Tindale, N. B., 1955, Archaeological site at Lake Menindee, New South Wales: Rec. S. Australian Mus., Adelaide, v. 11(3), p. 269-298.

1957. A dated Tartangan implement site from Cape Martin, East of South Australia: Trans. Royal Soc. S. Australia, v. 80, p. 109-123. - 1961, Archaeological excavation of Noola Rock Shelter. A preliminary report: Rec. S. Australian Mus., Adelaide, v. 14(1), p. 193-196.

Witty, T. A., 1962a, Archeological field work on the Kansas State Historical Society during the 1962 summer field season: Kansas Anthropol. Assoc. Newsletter, v. 8, no. 1, p. 3-9.

Assoc. Newsletter, v. 8 , no. 5

Yamane, T., and Fujiwara, M., 1956, The report of the historical investigation of the forbidden city of Naniwa: Osaka City Univ. Press. 